Open Access

\title{
Promoting ecosystem-friendly irrigation farm management practices for sustainable livelihoods in Africa: the Ghanaian experience
}

\author{
Caesar Agula ${ }^{1 *}$ (D), Mamudu Abunga Akudugu ${ }^{2}$, Franklin Nantui Mabe ${ }^{1}$ and Saa Dittoh ${ }^{3}$
}

\author{
* Correspondence: caesaragula@ \\ yahoo.com \\ ${ }^{1}$ Department of Agricultural and \\ Resource Economics, University for \\ Development Studies, Tamale, \\ Ghana \\ Full list of author information is \\ available at the end of the article
}

\begin{abstract}
The contribution of farming to food security, nutrition, employment and poverty alleviation in Africa cannot be overemphasised. This paper analysed the effects of adopting ecosystem-based farm management practices (EBFMPs) on the livelihoods of irrigation farmers in Africa, using Ghana as a case study. The paper employed mixed methods (qualitative and quantitative techniques) for purposes of triangulation and cross validation of the issues. Data were collected using key informant interviews, focus group discussions and administration of a questionnaire to 300 households. A treatment effect model was employed to estimate the effects of adopting EBFMPs on livelihoods of farmers. Specifically, the average treatment effect (ATE) and average treatment effect on the treated (ATET) were estimated and found to be positive and significant. This means that the adoption of EBFMPs has positive and significant implications for farmers' livelihoods. The paper therefore recommends that irrigation farmers should be educated on the importance of using ecosystem-friendly irrigation practices as this is critical for sustainable livelihood development of the poor and vulnerable, especially irrigators in Ghana who rely on the exigencies of the weather to survive. Irrigation farmers should also be educated on the functioning of irrigation landscape (in terms of water flow from up-stream area to down-stream), and how their activities and practices affect the irrigation water supply system.
\end{abstract}

Keywords: Ecosystems, Livelihoods, Farm management, Treatment effect, Irrigation

\section{Background}

The resilience of ecosystems in sustaining the livelihoods of people depends on the nature of interaction between society and the environment. According to Nzama (2009), ecological resource management and conservation has been identified as one of the key approaches that has the potential of enhancing and sustaining the livelihood conditions of most people, which include irrigation farmers. Modern agricultural production technologies, however, are putting stress on the ecological functioning of the ecosystems. There are rising concerns about the environmental risks associated with modern agricultural practices (Rezvanfar et al. 2009). One of the major risk factors is how to balance higher crop yields and agroecosystem sustainability by maintaining the fertility of the soil (Raghu and

(c) The Author(s). 2018 Open Access This article is distributed under the terms of the Creative Commons Attribution 4.0 International License (http://creativecommons.org/licenses/by/4.0/), which permits unrestricted use, distribution, and reproduction in any medium, provided you give appropriate credit to the original author(s) and the source, provide a link to the Creative Commons license, and indicate if changes were made. 
Manaloor 2014). This is particularly so in irrigated landscapes where there is intensive cultivation with most irrigation farmers adopting unsustainable farm-based practices with the aim of gaining higher yields with little recognition of the effect of those practices on the agroecosystems (Abdul-Hanan et al. 2014). The situation is exacerbated by population growth, which is mounting pressure on agricultural lands and the ecosystems because of increased food demands (Sterve 2011). The increased demand for food due to population growth has so far been met through expansion of agricultural lands and intensification of agriculture by the use of new technologies (Sterve 2011), which are often not ecosystem friendly. If this path of agricultural production should prevail for a longer period, the ability of the agroecosystems to provide essential services to humanity will worsen (Thiaw et al. 2011) and trap future generations in poverty through high cost of agricultural production (Millennium Ecosystem Assessment 2007).

The way to go is the use of sustainable farming practices for sustainable livelihoods, which is termed as ecosystem-based farm management practices (hereafter known as EBFMPs) in this paper. EBFMPs are farm-based practices employed by farmers to conserve soil fertility and improve the general health of agroecosystems for continuous delivery of ecosystem services. These practices can be indigenous farm-based practices adopted by farmers, which are essential in balancing agricultural output and the functional capacity of the agroecosystems in providing continuous services for present and future generations. On the average, the adoption of EBFMPs helps to maintain the fertility of agricultural lands through natural and biological means (Munang et al. 2011; Thiaw et al. 2011). They also balance nutrient requirement of crops resulting in more sustainable and resilient ecosystems (Rezvanfar et al. 2009). Specifically, the EBFMPs that are of interest in this paper include mulching, manure/compost application, crop rotation, efficient drainage systems, inter-cropping with legumes, soil/stone bunding, conservative tillage, and vegetation conservation. These practices are employed in irrigation and have implication on the health of irrigation ecosystems in terms of water flow in the whole irrigation landscape, soil fertility and vegetation. The aforementioned EBFMPs are usually used in combination. For example, an irrigator may employ two or more of these practices simultaneously on the farm within a single season. There might be trade-offs between higher yields and adoption of these EBFMPs in the short term. This is because the focus of the practices is not centred mainly on higher yields but for sustainable production and long-term irrigation ecosystem resilience for livelihoods.

Beyond the functional capacity of nature restoration, EBFMPs help to sustain livelihoods of many communities through sustainable irrigation and farming in general. The continuous provision of ecosystem services within an irrigation landscape will depend on the practices adopted in production (IUCN 2010). Following IUCN (2010), the resilience of agroecosystems within any geographic landscape can boost not only crop productivity but also reduce the cost of production. As such, sustaining agricultural lands has been of interest to many programmes and policies such as the Comprehensive Africa Agriculture Development Programme (CAADP) and the ECOWAS Agricultural Policy (ECOWAP) (Commission E 2009; Zimmermann et al. 2009). These policies and programmes aim at ensuring that expansion in food production does not compromise the biological sustainability of agricultural lands (Commission E 2009). However, the response to these policies and programmes, especially in Sub-Saharan Africa, has been low (Abdul-Hanan et al. 2014). Most farmers in the sub-region still employ farm-based practices that are 
environmentally unsustainable, which put the health of the agroecosystems in danger (Agula et al. 2018).

Most of the interventions on crop production in Ghana place importance on higher yields with little concern on sustainability of the ecosystems for continuous production. For example, the focus of the Ministry of Food and Agriculture (MoFA) in Ghana has been improving through dissemination of yield-enhancing technologies (Abdul-Hanan et al. 2014). Most of the yield-enhancing technologies aim to increase food availability (Nata et al. 2014), which often has a negative effect on the biological functioning of the agroecosystems (Sterve 2011). The effect of these yield-enhancing technologies extends further to affect most people's livelihoods that depend greatly on the services of the ecosystems (Davari et al. 2010). It is therefore important to promote the use of farming practices that do not negatively affect ecosystems' resilience and sustainability.

This paper argues that the adoption of ecosystem-friendly farming practices, both under irrigation and rain-fed conditions, positively and significantly affects the livelihoods of farmers, especially in rural Ghana where agriculture is the main livelihood activity. This position is based on the evidence provided by this paper that indicates that most farmers who make use of ecosystem-friendly farming practices are better off in the short to long term compared to their counterparts who do not. The rest of the paper provides some insights on the livelihoods and ecosystem nexus, empirical issues on livelihood evaluation, methodological insights on where the study was conducted and how the effects of adoption of ecosystem-friendly farming practices on livelihoods of farmers and farm households were estimated. These are followed by the results and discussion as well as conclusion and policy implications.

\section{Empirical review of livelihood and ecosystem services}

The livelihood and ecosystem service nexus-conceptual and empirical issues

The existence of human beings and all living organisms have a direct correlation with the health of the ecosystems. As such, efficient management of the ecological and ecosystem resources is key for sustaining the livelihoods of most people (Nzama 2009). Livelihood is a social concept and currently has greater currency and a wider appreciation than poverty as it comprises of people, their capabilities, assets (including both material and social resources) and activities required for a means of living (Meikle et al. 2001; Sheheli 2012). For livelihood to be sustainable, it must be resilient to shocks and stresses and must also not adversely affect the environment (Meikle et al. 2001). This means that the health of the ecosystems constitutes a major determinant in dictating how sustainable a group of people's livelihood will be. The driving force of the concept of livelihood is based on capital assets, which include the human capital, natural capital, physical capital, financial capital, political capital and social capital (UNDP 2013).

Various studies (e.g. IUCN 2004; Millennium Ecosystem Assessment 2005; Millennium Ecosystem Assessment 2007; Hancock 2010) have been carried out which tie ecosystem conservation practices with that of livelihoods. According to the Millennium Ecosystem Assessment Report (2007), ecosystem conservation practice is a principal driver of poverty alleviation and enhances general socio-economic conditions of people. The report asserts that majority of the world's population, especially the poor and vulnerable, have their livelihood engagements depend strongly on the ecosystems. Similarly, IUCN (2004) suggested that what makes ecosystem restoration practices (including the adoption of EBFMPs) uniquely 
valuable is their inherent capacity to provide people with the opportunity not only to improve on their livelihood conditions but also to repair ecological damage. The benefits of ecosystem restoration are obvious since they can improve biodiversity conservation and ecosystem productivity, empower local people and aggregately improve livelihoods (IUCN 2004). What is also very important is the ability of those conservative ecosystem practices to renew economic opportunities and subsequently contribute to the improvement of human well-being (IUCN 2004; Hancock 2010).

A study in the Dominican Republic by Gross et al. (2014) revealed that a coordinated effort to support smallholder shade coffee farmers offers a better potential to improve on rural livelihoods and the resilience of the ecosystem services than the practice of cutting down trees. The reason is that unsustainable tree-cutting practices for high-input monoculture cropping to meet the household economic pressures rather threaten natives' tree biodiversity and the provision of ecosystem services (e.g. delivery of clean water and carbon sequestration) to local beneficiaries. Findings from Sudmeier-Rieux et al. (2006) also suggest that well-managed productive ecosystems can support sustainable income-generating activities and are equally important assets for people and communities even in the aftermath of disasters such as drought and floods. This is because a healthy ecosystem has the capacity to mitigate quickly the impact of most natural hazards and provides a lot of livelihood alternatives (e.g. the provision of fruits) that people can depend on. Even in the era where climate change and environmental variability is having an overwhelming impact on the economic conditions of rural households, ecosystem conservation and sustainable development interventions have been posited as the most effective approach in addressing both environmental degradations and households' livelihood conditions (Assan and Beyene 2013). Again, a situational report on the link between ecosystem services and poverty alleviation suggests that investments in managing and securing ecosystem services alone can eradicate poverty in the arid and semi-arid lands of Southern Africa (Shackleton et al. 2008). The report further indicates that ecosystem services contribute in diversifying livelihood portfolios, both home consumption and income generation.

At the country level, studies in Ghana (e.g. Mwingyine 2008; Hapsari 2010; Boon and Ahenkan 2012; Boafo et al. 2014; Wiafe and Arku 2014) have been carried out which link people's livelihoods to the resilience of the ecosystems. According to Mwingyine (2008), about 93\% of the people of Sissala West District of Ghana depend on the health of the ecosystems as they engage in farming as their major source of livelihood. The study specifically reported that non-sustainable land use practices pose serious threats to livelihoods as the land is fast degrading and people are sinking gradually into poverty. The author further noted that agricultural activities such as land preparation, continuous cropping, farming near water courses, grazing activities and wood harvesting for various purposes are major contributory factors to loss of soil fertility, drying up of water bodies and worsening of rainfall patterns in the area. These environmental problems impact negatively on ecosystems and their ability to support livelihoods. Boafo et al. (2014) also looked at how the services of ecosystems affect rural livelihoods in the Tolon and Wa-West Districts of Ghana. The study found that approximately $80 \%$ of participating households depend primarily on ecosystem services for livelihood sustenance. On the services of ecosystems, Wiafe and Arku (2014) showed how the livelihoods of women are affected with the Afadjato mountain ecosystem in Ghana. According to Wiafe and Arku (2014), the women benefit from a variety of resources from the mountain ecosystem that vary from food to other resources such 
as fuelwood and fresh water. The general effect of ecosystems on livelihoods is enormous in Ghana as many communities including those around Sui River Forest Reserve are dependent on the reserve for their livelihoods (Boon and Ahenkan 2012). It is therefore clear that there are direct relationships between ecosystems and livelihoods of most households, especially in Ghana and most parts of Africa.

Impact evaluations on household's livelihood-empirical studies on treatment effect

To measure the impact of an intervention or technology on livelihood, the choice of a model then becomes critical in ascertaining the true effect of that particular technology (herein referred to as EBFMP adoption). Issues of selection bias surround the adoption of technology. Treatment effect is therefore usually employed to solve this problem in data collection and to obtain robust estimates that give a true reflection of impact of the technology on livelihood.

In measuring the impact of irrigation on health and environmental sustainability in Africa, Akudugu et al. (2016) employed an average treatment effect (ATE) model to assess the true effect on the irrigators. The individual farmers, household and irrigation characteristics such as respondent's age, gender, marital status, household size, education, generation, gender of household head among others were used in the estimation of the selection equation. The study revealed mixed impacts of irrigation on health and environmental sustainability. The positive impacts are irrigators' ability to pay improved health care for themselves and families, while the negative impacts are due to the outbreak of waterborne diseases associated with irrigation water.

The ATE method was also employed by Ogunniyi and Kehinde (2015) to assess how the use of innovative agricultural research impact on livelihood and productivity outcomes of rural smallholder farmers in Nigeria. The explanatory variables that were expected to jointly determine the probability to participate in the treatment and the outcome include age of household head, education, marital status, household size, farm size, gender and occupation. The study established that rural incomes and output are significantly impacted upon by agricultural research interventions driven by innovation system concepts. In Ghana, Acheampong and Owusu (2015) considered the impact of improved cassava varieties' adoption on incomes of farmers. The ATE suggested that there was an increase in the total crop incomes of farmers per hectare and the variables expected to influence both adoption and welfare (measured by income) include farm and farmer characteristics, institutional and access-related variables and technology characteristics.

Again, in considering the impact of micro credit on the livelihood of borrowers from Mekelle City of Ethiopia, an ATE model was employed (Diro and Regasa 2014). The study outcome suggests that microcredit participation has positive effect on household's livelihood-average monthly income, consumption expenditure, savings and housing improvements. Variables like age of the household, sex, number of dependents, spouse of household head and credit access were used for matching purposes. The ATE method was also used by Kebebe and Shibru (2017) to assess the impact of participating in alternative livelihood activities on household welfare and environmental protection in rural Ethiopia. The empirical results indicate that participation in alternative livelihood activities contributed to increased grain production, household income and employment of natural resource management technologies. It can therefore be diagnosed that individual farmer and 
household characteristics, farm characteristics, off-farm economic activities and remittances should be considered when measuring the effect of EBFMPs on livelihoods of farmers.

\section{Methods}

\section{Study setting and sampling process}

The study was conducted in the Upper East Region of Ghana. Ghana has varied agro-ecological zones which include the Rain Forest Zone, Coastal Savannah Zone, Semi-deciduous Forest Zone, Transitional Zone, Guinea-Savannah Zone and Sudan-Savannah Zone. The varied nature of the agro-ecological zones in Ghana makes her fairly representative of Africa, which has similar agro-ecological zones. The selection of the Upper East Region of Ghana was due to the fragile nature of its ecosystems, which is a common characteristic of most of sub-Saharan Africa. In other words, the fragile nature of the ecosystems means that there is the need to adopt farming practices that do not further deteriorate the capacity of the ecosystems to continue to play the key functions in maintaining human life.

Specifically, the Kassena-Nankana area (Kassena-Nankana West District and Kassena-Nankana East District) was selected because of the presence of small- and large-scale irrigation schemes that play key roles in sustaining livelihoods of the people in the area and beyond. The study districts (Fig. 1) fall within the Sudan-Savannah Vegetation Zone and has a total population of about 181,000 with about $61 \%$ from the Kassena-Nankana East District and 39\% from the Kassena-Nankana West District (GSS 2012). The predominant economic activity in the area is farming with about $69 \%$ of the total population into agriculture (Dinye 2013).

A three-stage sampling technique was used to select the study communities and households. In the first stage of the sampling, because of the critical role of irrigation in ensuring sustainable agricultural production, communities in the two districts were divided into strata of community-managed and government-managed irrigation schemes of which three

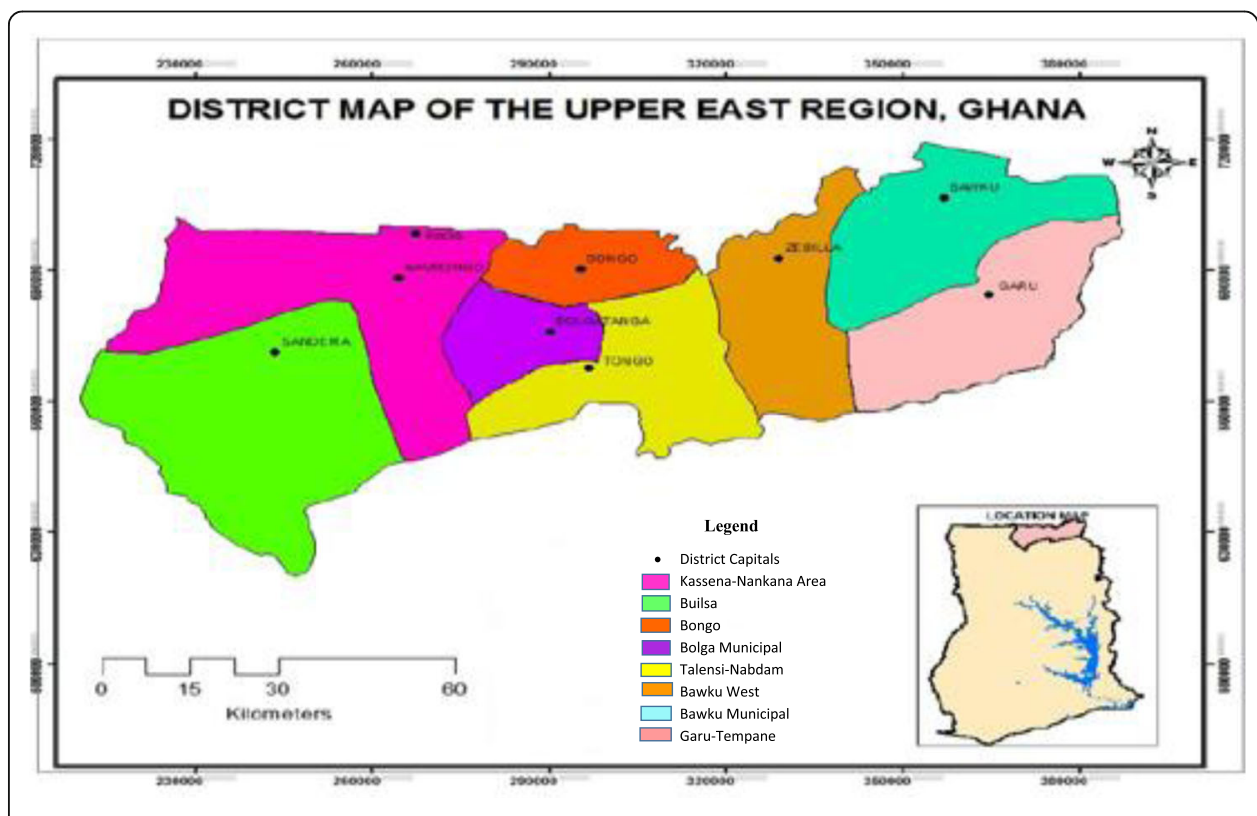

Fig. 1 A map of Kassena-Nankana Area in the Upper East Region of Ghana. Source: Dinye and Ayitio (2013) 


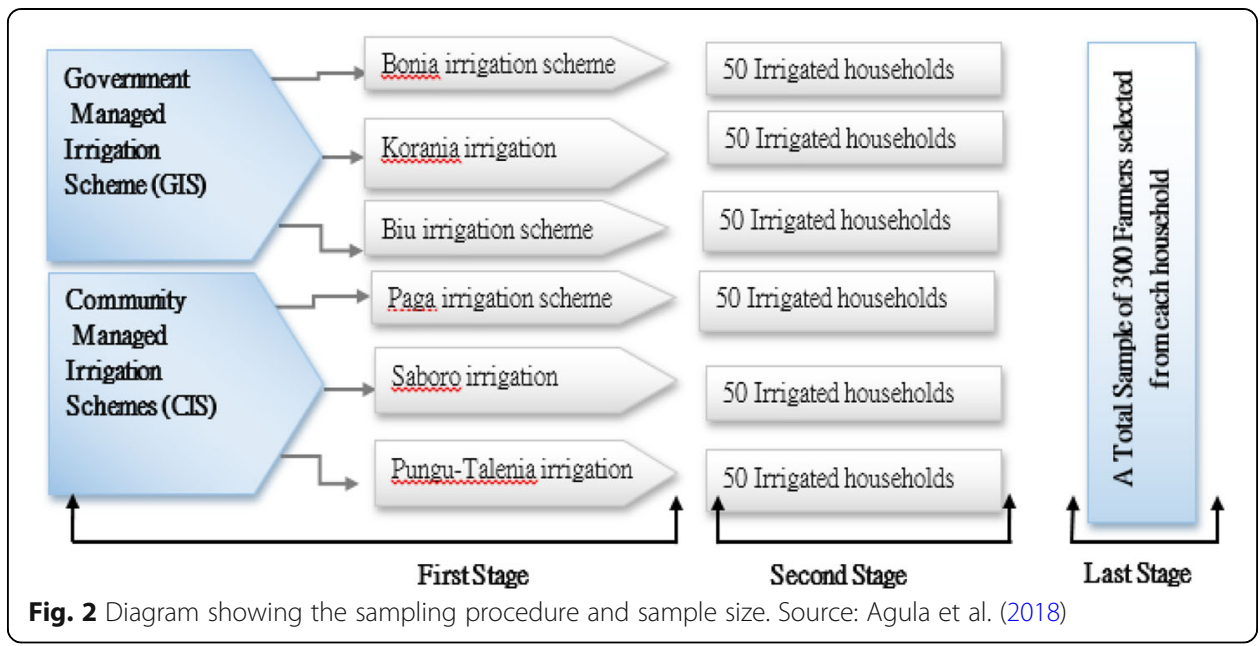

(3) communities each were randomly selected from each stratum (Fig. 2). The categorisation of irrigation systems in this paper is based on management. Community-managed irrigation schemes (CIS) are small irrigation schemes where the irrigators access their water from a common community dam and manage their own irrigation activities. The irrigable lands and reservoirs for CIS are relatively small compared to government-managed irrigation schemes (GIS). The CIS have an average number of 150 irrigators per community and a mean farm size of about 0.5 acre for each irrigator. On the other hand, GIS are large irrigation schemes where irrigators can access their water from a common reservoir that supplies water across a number of communities and with a structured management system by a government or non-governmental organisation. The GIS usually have a large population of irrigators and irrigable farm size relative to the CIS. For instance, the average number of irrigators per community under GIS is about 205 farmers and with a mean farm size of about 1.5 acres per irrigator.

In the second stage, a simple random sampling technique was used to select the required number of irrigated households from each community. From a sample frame of 1813 households, 300 households representing about $17 \%$ of the sample frame were selected randomly for the study with each community having 50 households as shown in Fig. 2. The 50 households from each community are more than $20 \%$ of the total households in the community and, thus, representative of the community. Again, the selection of the $17 \%$ of the target population is consistent with the view of Agula et al. (2018) that a sample of 10 to $20 \%$ of any population is always enough to generate confidence in the data collected and for subsequent generalisations. In the last stage, one irrigator was randomly selected from each irrigated household for the questionnaire administration.

\section{Household characteristics of irrigators}

Majority of the farmers in Ghana are into small-scale farming and traditional in their practices. Most of these traditional or indigenous practices (which many are classified as EBFMPs) are ecosystem-friendly. They are therefore employed in irrigation to improve the health of the agro-ecosystems. Usually, an irrigator employs at least one of these EBFMPs on their farmlands, since they are indigenous in nature and learnt from forefathers (Table 1). In 
Table 1 Count distribution of EBFMPs

\begin{tabular}{ll}
\hline Total EBFMPs adopted in irrigation & Percentage $(n=300)$ \\
\hline 1 & 7.33 \\
2 & 13.33 \\
3 & 34.67 \\
4 & 19.33 \\
5 & 14.33 \\
6 & 7.33 \\
7 & 2.67 \\
8 & 1.00 \\
\hline
\end{tabular}

Source: Field survey, 2016

that regard, the paper categorised the irrigators based on the mean number of EBFMPs adopted (where the computed mean $=3.57$ ). The first category being "below average adopters" comprises of irrigators who employed less than four EBFMPs and the second category termed "above average adopters" comprises of irrigators who employed four and more EBFMPs. The purpose of this classification is to help determine the effect of adopting more EBFMPs on the livelihoods of the farmers.

Most of the irrigators in the study area fall within the productive age cohort with an average age of about 39 and 45 years respectively for below and above average adopters, and with their corresponding standard deviations of about 10 and 11 years respectively (Table 2). This outcome is however statistically significant at $1 \%$. The reason being that irrigation farming has become an attractive venture for many young people, especially in Ghana. Crops such as pepper, onions, tomatoes, and rice among others offer relatively good market prices, and these crops are mostly irrigated by the productive age cohort. Again, most of the agricultural lands owned by government-managed irrigation schemes (GIS) are operated as an open access system where the youth have an equal chance of securing lands for farming. The paper also found that majority of the farmers are males and this emanates from the cultural and social setting of the people (Table 2). Until recently, women in many parts of Africa were traditionally in-charge of sales of farm produce and petty trading while farming was culturally seen as a male-dominated economic activity. Productive agricultural lands in Ghana are owned and controlled by men, making the sector male-dominated. The focus group discussions revealed that women farm on relatively small farm size, enabling them to employ more EBFMPs.

Table 2 shows that majority of the farmers had no formal education or had only basic education. The respondents' level of education shows that approximately $34 \%$ had at least Junior High School (JHS) education. This implies that only a few of the farmers might be able to read and understand new agricultural technologies and interventions. Agriculture is yet to acquire the needed level of investment in Ghana, which can attract graduates from the tertiary level. As such, it is characterised by farmers with greater weakness in reading and understanding new agricultural interventions or programmes. This tend to affect farmers' understanding of the nexus between new agricultural interventions and agro-ecosystem sustainability; hence, they adopt practices that are not ecosystem-friendly.

The survey also revealed that the farm sizes of irrigators who adopt above average number of EBFMPs are relatively small compared to below average adopters. On the average, irrigators under above average adopters' cohort cultivate less than 1 acre while those under below average adopters cultivate more than 1 acre (Table 2). This is statistically significant 
Table 2 Summary of household characteristics

\begin{tabular}{|c|c|c|c|c|c|c|}
\hline \multirow[t]{2}{*}{ Continuous variables } & \multicolumn{2}{|l|}{ Mean $(n=300)$} & \multicolumn{2}{|c|}{$\begin{array}{l}\text { Standard } \\
\text { Deviations }\end{array}$} & \multicolumn{2}{|c|}{$\begin{array}{l}t \text {-test (mean } \\
\text { comparison } \\
\text { test) } d f=289\end{array}$} \\
\hline & $\begin{array}{l}\text { Below average } \\
\text { adopters }(n=166)\end{array}$ & $\begin{array}{l}\text { Above average } \\
\text { adopters }(n=134)\end{array}$ & $\begin{array}{l}\text { Below } \\
\text { average } \\
\text { adopters }\end{array}$ & $\begin{array}{l}\text { Above } \\
\text { average } \\
\text { adopters }\end{array}$ & $t$ value & $\operatorname{Pr}(|T|>|t|)$ \\
\hline Age & 38.674 & 45.298 & 10.576 & 10.757 & -5.351 & 0.000 \\
\hline Household size & 5.650 & 5.940 & 2.207 & 2.565 & -1.050 & 0.294 \\
\hline $\begin{array}{l}\text { Farm size for irrigation } \\
\text { (acres) }\end{array}$ & 1.342 & 0.854 & 1.059 & 0.763 & 4.475 & 0.000 \\
\hline $\begin{array}{l}\text { Farm income for irrigation } \\
(\mathrm{GHS})\end{array}$ & 6955.322 & 4958.172 & 7720.930 & 6299.212 & 2.414 & 0.016 \\
\hline $\begin{array}{l}\text { Farm income for rain-fed } \\
(\mathrm{GHS})\end{array}$ & 3020.587 & 2637.903 & 2802.323 & 3256.764 & 1.093 & 0.275 \\
\hline \multirow[t]{2}{*}{ Categorical variables } & \multicolumn{3}{|l|}{ Percentage } & \multirow{2}{*}{\multicolumn{2}{|c|}{ Pearson chi ${ }^{2}(1)$}} & $P$ value $(\mathrm{Pr})$ \\
\hline & $\begin{array}{l}\text { Below average } \\
\text { adopters }(n=166)\end{array}$ & $\begin{array}{l}\text { Above average } \\
\text { adopters }(n=134)\end{array}$ & $\begin{array}{l}\text { Total } \\
(n=300)\end{array}$ & & & \\
\hline \multicolumn{7}{|l|}{ Sex } \\
\hline Male & 41.00 & 30.00 & 71.00 & \multirow{2}{*}{\multicolumn{2}{|c|}{1.7305}} & 0.188 \\
\hline Female & 14.33 & 14.67 & 29.00 & & & \\
\hline \multicolumn{7}{|l|}{ Marital status } \\
\hline Married & 38.67 & 26.67 & 65.33 & \multirow{2}{*}{\multicolumn{2}{|c|}{3.3913}} & 0.066 \\
\hline $\begin{array}{l}\text { Otherwise (single, } \\
\text { separated and widowed) }\end{array}$ & 16.67 & 18.00 & 34.67 & & & \\
\hline \multicolumn{7}{|l|}{ Household head } \\
\hline Yes & 37.67 & 33.33 & 71.00 & \multirow{2}{*}{\multicolumn{2}{|c|}{1.5471}} & 0.214 \\
\hline No & 17.67 & 11.33 & 29.0 & & & \\
\hline \multicolumn{7}{|l|}{ Education } \\
\hline $\begin{array}{l}\text { Had formal education } \\
\text { (JHS and above) }\end{array}$ & 19.67 & 14.67 & 34.33 & \multirow{2}{*}{\multicolumn{2}{|c|}{0.2409}} & 0.624 \\
\hline $\begin{array}{l}\text { Below Junior High } \\
\text { School }(J \mathrm{HS}) \text { education }\end{array}$ & 35.67 & 30.00 & 65.67 & & & \\
\hline \multicolumn{7}{|l|}{ Off-farm income } \\
\hline Yes & 17.33 & 31.00 & 48.33 & \multirow{2}{*}{\multicolumn{2}{|c|}{43.0502}} & 0.000 \\
\hline No & 38.00 & 13.67 & 51.67 & & & \\
\hline
\end{tabular}

Source: Field survey, 2016

at $1 \%$. The reason being that having a small farm size makes it less laborious for irrigators to employ more EBFMPs. The small farm size also explains why farmers under above average adopters' category have less income from irrigation compared to their counterparts (Table 2). From the table, the average income from irrigation is about GHS 7000.00 and GHS 5000.00 respectively for below average and above average adoption groups. This is also statistically significant at $5 \%$.

Again, the survey revealed that the mean household size of the irrigation farmers is a little over five and about six for below and average adopters respectively, and with standard deviations of about 2 and a little over 2 (Table 2). This means that averagely households have large potential labour force to help in farming activities. It can be observed in Table 2 that about $65 \%$ of the respondents are married while $35 \%$ otherwise (single, separated and widowed), and this is also statistically significant at the $10 \%$ level. The table also shows that 
$71 \%$ of the respondents are household heads while $29 \%$ are not. Some household heads lost their spouses and some are staying with their children alone because of broken homes. Details of farmers' household characteristics are shown in Table 2.

\section{Study methods and analytical model}

The paper employed a sequential mixed methods approach where the qualitative study using key informant interviews and focus group discussions preceded the quantitative method using a semi-structured questionnaire. The main advantage of using the sequential mixed methods is that the results of the first method are fed into the second method such that the research problem is holistically addressed from different viewpoints through systematic triangulations. Thus, the results of the key informant interviews and focus group discussions helped in the design of the quantitative aspect of the study. In other words, the results of the qualitative study made it possible for us to identify areas that needed more detailed and quantitative information, which informed the type of questions asked in the semi-structured questionnaire. Analytically, a treatment effect model (adjustment regression) was employed to examine the effects of EBFMPs on the livelihoods of farmers. However, in measuring livelihood, an average livelihood status score (index details shown in Appendix) was used to measure the livelihoods of farmers.

\section{Conceptual framework of treatment effect and model specification}

The main problem average treatment effect seeks to solve is selection bias between treatment group (herein referred to as "above average adopters" of EBFMPs) and comparison group (herein referred to as "below average adopters" of EBFMPs). From Akudugu et al. (2016), farmers choose to adopt (here, become above average adopters) or not to adopt (become below average adopters) technology (EBFMPs) depending on their inherent characteristics and other unobservable attributes. This is referred to as self-selection and it implies that the estimation of adoption impact resulting from a simple difference between the treatment and comparison groups fail to properly control for potential differences among the two groups (Acheampong and Owusu 2015). The reason being that it tends to overestimate the impact of adoption on the outcome variable (herein referred to as livelihood). This evaluation problem is caused by missing data, which arises from the fact that individuals cannot be in both treatment and comparison groups. In other to deal with this, therefore, the study employed an average treatment effect model (regression adjustment) that allows for true effect of the treatment on livelihoods of farmers to be determined. The regression adjustment model goes beyond the idea of using sample means to estimate treatment effects but rather, it uses a regression model to predict potential outcomes adjusted for the covariates. ${ }^{1}$ According to Verbeek (2008), the treatment effects are computed mathematically as follows:

$$
t_{i}=\text { treatment category }\left(\frac{t_{i}=1 \text { for treatment }}{t_{i}=0 \text { for otherwise }}\right)
$$

The treatment category can be likened to adoption category of this study, where $t_{i}=1$ represents above average adopters of EBFMPs and $t_{i}=0$ represents below average adopters of EBFMPs.

In this paper, a farmer is classified as an above average adopter of EBFMPs if he/ she uses four (4) or more EBFMPs. A farmer who uses less than four (4) is classified as below average adopter. 
$y_{0 i}=$ potential outcome of livelihood score for $i$ th farmer if below average adopter

$y_{1 i}=$ potential outcome of livelihood score for $i$ th farmer if above average adopter then,

$$
\mathrm{ATE} \equiv E\left\{y_{1 i}-y_{0 i} \mid x_{i}\right\}
$$

where

$$
\begin{aligned}
& \text { ATE = average treatment effect } \\
& x_{i}=\text { characteristics of } i \text { th farmer }
\end{aligned}
$$

This estimation is, however, still criticised in the sense that it does not give the effect on only those who have received treatment (Verbeek 2008), which in this case is above average adopters. In that regard, it will be prudent if the population of interest is properly specified by employing the average treatment effect on the treated (ATET). This is mathematically represented as:

$$
\mathrm{ATET}=E\left\{y_{1 i}-y_{0 i} \mid x_{i}, t_{i}=1\right\}
$$

From Verbeek (2008), the potential outcome model specifies that the observed livelihood score $(y)$ is $y_{0}$ when the adoption category $(t)=0$ and that $y$ is $y_{1}$ when $t=1$. This is expressed mathematically as:

$$
y=(1-t) y_{0}+t y_{1}
$$

The functional forms for $y_{1}$ and $y_{0}$ are:

$$
\begin{aligned}
& y_{0}=x^{\prime} \beta_{0}+\varepsilon_{0} \\
& y_{1}=x^{\prime} \beta_{1}+\varepsilon_{1}
\end{aligned}
$$

The empirical representations for determining the treatment effects of EBMFP adoption on livelihoods of farmers are expressed $\mathrm{as}^{2}$ :

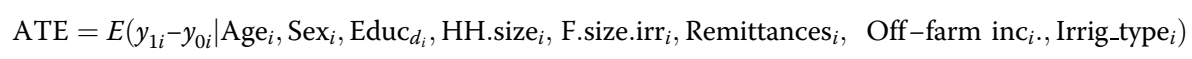

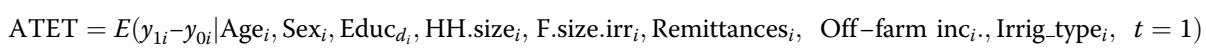

The empirical representation of the potential outcome model for above average adopters of EBFMPs is:

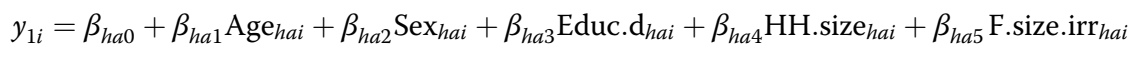

$$
\begin{aligned}
& +\beta_{h a 6} \text { Remittances }_{h a i}+\beta_{h a 7} \text { Off-fm.inc } h a i+\beta_{h a 8} \text { Irrig.type }_{h a i}+\varepsilon_{h a i}
\end{aligned}
$$

The empirical representation of the potential outcome model for below average adopters of EBFMPs is: 


$$
\begin{aligned}
y_{0 i}=\beta_{l a 0}+\beta_{l a 1} \text { Age }_{l a i} & +\beta_{l a 2} \operatorname{Sex}_{l a i}+\beta_{l a 3} \text { Educ.d }_{l a i}+\beta_{l a 4} \text { HH.size } \\
& +\beta_{l a i} \text { Remittances }_{l a i}+\beta_{l a 5} \text { F.size.irr }_{l a i} \text { Off-fm.inc } \\
l a i & +\beta_{l a 8} \text { Irrig.type }_{l a i}+\varepsilon_{l a i}
\end{aligned}
$$

The variables modelled are described in Table 3.

\section{Development of farmers' livelihood score}

The indicators that were used to measure the livelihoods of farmers include food availability, housing condition, health situation, water facilities, sanitation, participation in social activities, decision-making in cash expenditure (Sheheli 2012), health of the ecosystem services and income. The average livelihood status score (ALSS), adopted and modified from Sheheli (2012), was used to measure the livelihood status of the farmers. The ALSS is calculated in two steps. First, individual farmer's indicator percentage score (IFIPS) is determined for each of the livelihood indicators. Second, the average livelihood status score (ALSS) is computed on the score of the identified livelihood indicators. Thus, the first step is the calculation of IFIPS as follows:

$$
\mathrm{IFIPS}_{i}^{k}=\frac{\mathrm{IFFS}_{i}^{k}}{\mathrm{IFPMS}^{k}} \times 100
$$

where

IFIPS $_{i}^{k}=$ the score of $k$ livelihood indicator for $i$ th farmer

IFFS $_{i}^{k}=$ the field score of $k$ livelihood indicator for $i$ th farmer

IFPMS $^{k}=$ the maximum possible score for $k$ livelihood indicator

The second step is the calculation of the average livelihood status score (ALSS) as follows:

$$
\mathrm{ALSS}_{i}=\frac{\sum_{k=i}^{k=9} \operatorname{IFIPS}_{i}^{k}}{n_{k}}
$$

where

$$
n_{k}=\text { number of livelihood indicators }=9
$$

Table 3 Definition of variables and a priori expectations for treatment effect model

\begin{tabular}{llll}
\hline Variable & Variable definition & Units of measurement & $\begin{array}{c}\text { Expected } \\
\text { sign }\end{array}$ \\
\hline ALSS & Average livelihood status score & Index of livelihood indicators \\
Age & Age & Years & $+/-$ \\
Sex & Sex & Dummy $(1=$ female, $0=$ male $)$ & $+/-$ \\
Educ.d & Education & Dummy $(1=$ had formal education (JHS and above), & + \\
& & $0=$ otherwise $)$ & + \\
HH.size & Household size & Number of people in household & + \\
F.size & Irrigable farm size & Acres & + \\
Remittances & Remittances & Ghana cedi & + \\
Off-fm.inc & Off-fm income & Ghana cedi & $+/-$ \\
Irrig_type & Category of irrigation & Dummy (1=CIS, 0 = GIS) &
\end{tabular}

Source: Authors' construct, 2016 


$$
\sum_{k=i}^{k=9} \operatorname{IFIPS}_{i}^{k}=\text { sum of individual farmer's indicator percentage score }
$$

\section{Results and discussion}

The paper sought to examine how ecosystem-friendly irrigation farm management practices for sustainable livelihoods could be promoted in Ghana and Africa on a broader scope. In doing so, nine (9) indicators were indexed to measure livelihoods. A treatment effect model was then employed to examine the livelihood effect of adoption of ecosystem-friendly irrigation farming practices herein collectively referred to as ecosystem-based farm management practices (EBFMPs) in this paper. Eight EBFMPs were under consideration for the study and among the practices, conservative tillage, conservation of vegetation, organic manure application and mulching were predominantly employed by the farmers (Table 4). The various implications of EBFMP adoption on households' livelihoods are set out in the next subsections.

\section{Implication of EBFMPs on soil fertility and cost of production}

It was revealed from the focus group discussions that the use of more EBFMPs on irrigation farmlands does not only improve soil fertility but also serves as a restoration mechanism for irrigation ecosystems. The adoption of organic manure application, mulching, conservative tilling, intercropping with legumes and crop rotation helps to improve soil fertility biologically, thus lessening the cost of production. Usually, farmers who employ less or no EBFMPs incur greater expenditure on the purchase of inorganic fertilisers and chemicals for controlling pests and diseases. Figure 3 shows that farmers who adopt above average number of EBFMPs have more resilient irrigation ecosystems that provide a range of services to households compared to those who adopt below average number of EBFMPs.

\section{Implication of EBFMPs on vegetation restoration, food security and health}

The conservation of vegetation helps to maintain the health of the agroecosystems, which provide a lot of services such as fruits, grasses and fodder for human and livestock. Most households conserving their irrigation vegetation feed on fruits (such as mangoes, shea fruits, ebony fruits and other wild fruits), especially in the long dry seasons. Income is also generated from sale of the fruits, and extraction of oil from the shea nuts. Beyond this, the contribution of the vegetation toward herbal medicine for households' ailments is

Table 4 Distribution of EBFMPs adopted by farmers

\begin{tabular}{|c|c|c|c|}
\hline \multirow[t]{2}{*}{ EBFMPs adopted } & \multicolumn{3}{|l|}{ Percentages } \\
\hline & $\begin{array}{l}\text { Below average } \\
\text { adopters }(n=166)\end{array}$ & $\begin{array}{l}\text { Above average } \\
\text { adopters }(n=134)\end{array}$ & Pooled $(n=300)$ \\
\hline Compost or organic manure application & 42.77 & 79.85 & 59.33 \\
\hline Conservative tillage & 37.95 & 84.33 & 58.67 \\
\hline Intercropping with legumes & 30.12 & 46.27 & 37.33 \\
\hline Crop rotation & 27.11 & 41.04 & 33.33 \\
\hline Mulching & 17.47 & 72.39 & 42.00 \\
\hline Conservation of vegetation & 49.40 & 83.58 & 64.67 \\
\hline Efficient drainage system & 19.88 & 53.73 & 35.00 \\
\hline Soil bunding & 24.70 & 30.60 & 27.33 \\
\hline
\end{tabular}

Source: Field survey, 2016 


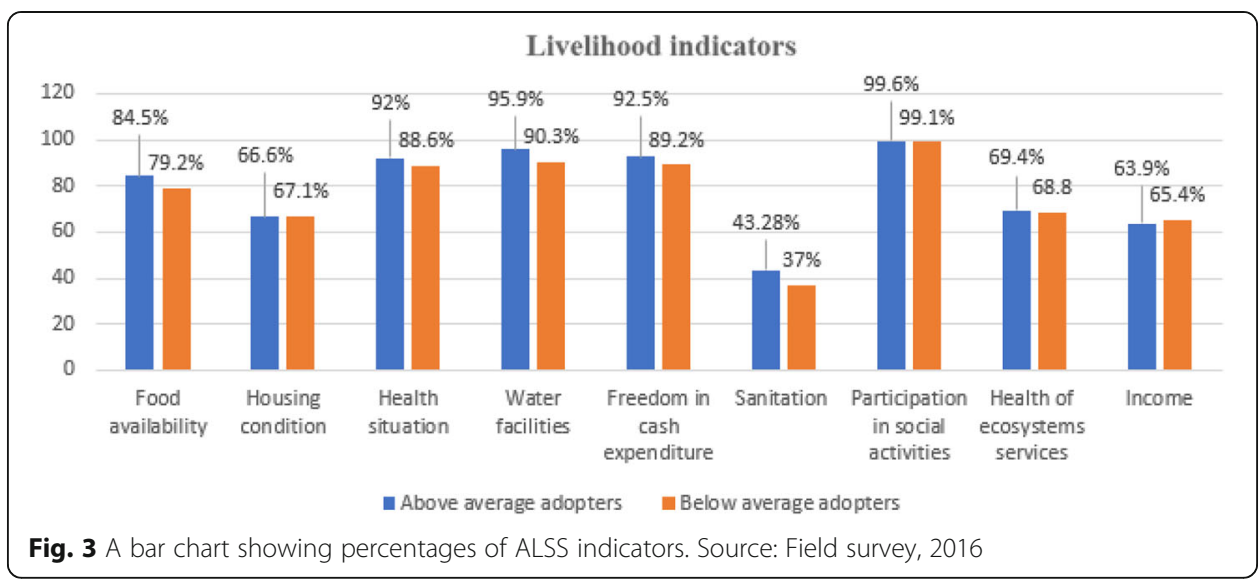

enormous, as shown in Fig. 3. The figure reveals that above average adopters have a high livelihood score (92\%) on their health situation compared to those who are below average adopters (about $89 \%$ ). Income is equally generated from the sale of the herbal products obtained from irrigation ecosystems.

Implication of EBFMPs on irrigation water supply, aquatic life and livestock

The adoption of efficient drainage systems and soil bunding help to maximise irrigation water usage and preserve aquatic life for households' livelihoods. Activities of farmers affect the supply of water within an irrigation landscape (that is, catchment area, up-stream, mid-stream and down-stream). From the focus group discussions, farmers indicated that those who adopt efficient drainage systems and soil bunding have sustainable water flow throughout the season within their farmlands for crops and livestock. In addition, efficient drainage systems and practices have direct effect on aquatic life and domestic water requirements. Aquatic life depends on the health of the water, and the health of irrigation water also depends on the activities and practices of irrigators. From Fig. 3, farmers who adopted above average number of EBFMPs have a higher livelihood score on water facilities (about 96\%) than those who have adopted below average number of EBFMPs (about 90\%).

\section{Implication of EBFMPs on income and yield}

Mostly, there are trade-offs between sustainability and yield in the short term. In the same vein, the adoption of EBFMPs has an effect on income negatively. It is revealed from the survey that farmers who adopt fewer numbers of EBFMPs usually cultivate on a large scale with high inorganic fertiliser application, hence obtaining high yields and income (Fig. 3). However, this affects their cost of production and profit margins in the long term and sometimes in the immediate term. The figure shows that farmers who have adopted below the average number of EBFMPs have a high livelihood score on income (about 65\%) while those who have adopted above the average number of EBFMPs have a low livelihood score (about 64\%).

\section{Implications on livelihood by the ATE, ATET and potential outcome means}

The result of the average treatment effect (ATE) model suggests that being above average adopter of EBFMPs has a positive effect on the livelihoods of farmers (Table 5). This finding is statistically significant at $1 \%$, and in terms of magnitude, the result shows that if farmers 
Table 5 Average treatment effect (ATE) on farmers' livelihoods

\begin{tabular}{lcc}
\hline Variables & Coefficients & Robust standard error \\
\hline Average treatment effect (ATE) & & .569 \\
Category (above average adoption vs. below average adoption) & $2.977^{* * *}$ & \\
Potential outcome mean & $75.757^{* * *}$ & \\
Category (below average adoption) & \\
$\quad$ Number of observations $=300$ & \\
Iteration 0: EE criterion $=8.657 \mathrm{e}-28$ & \\
Iteration 1: EE criterion $=7.733 \mathrm{e}-30$ & \\
$\quad$ Outcome model: linear & \\
$\quad$ Treatment model: none & \\
\hline Values statistically significant at $1 \%$ & \\
Source: Field survey, 2016 &
\end{tabular}

decide to adopt above average number of EBFMPs, they will experience about 3\% improvement in their livelihood scores (ALSS). This means that adoption of EBFMPs in farming is not only a sustainability measure but also helps to improve the livelihoods of farmers in Ghana. This is consistent with IUCN (2004), which suggested that ecosystem restoration practices are uniquely valuable because of their inherent capacity to provide people with the opportunity not only to improve their livelihood conditions but also to repair ecological damage caused by continuous agricultural production and related livelihood activities. For instance, the adoption of EBFMPs protects irrigation landscapes thereby conserving the environment for sustainable livelihoods. A minimum destruction to the vegetative cover means availability of ecosystem services, particularly services such as grasses for livestock, fruits for humans and fresh water for human beings and aquatic life.

The results in Table 6 further suggest that the decision to adopt above average number of EBFMPs leads to an increase of over 3\% in the livelihood of farmers and this is statistically significant at $1 \%$. The ATET is considered as the true effect of EBFMP adoption because the effect is analysed on only farmers who are above average adopters. The outcome re-emphasises the importance of adopting more EBFMPs and how it sustains economic activities for livelihood development.

In addition, there was further analysis to find out what the likely effects of adoption of EBFMPs on livelihoods will be if all farmers decided to adopt either an above or below average number of EBFMPs. This was done through the potential outcome means (POMs).

Table 6 Average treatment effect on the treated (ATET)

\begin{tabular}{lcc}
\hline Variables & Coefficients & Robust standard error \\
\hline ATE on the treated & & .698 \\
Category (above average adoption vs. below average adoption) & $3.295^{* * *}$ & .622 \\
Potential outcome mean & $75.344^{* * *}$ & \\
Category (below average adoption) & \\
$\quad$ Number of observations $=300$ & \\
Iteration 0: EE criterion $=8.509 \mathrm{e}-28$ & \\
Iteration 1: EE criterion $=1.870 \mathrm{e}-29$ & \\
Outcome model: linear & \\
Treatment model: none &
\end{tabular}

***Values statistically significant at $1 \%$

Source: Field survey, 2016 
Potential outcome means are the averages of the predicted livelihoods of farmers based on their category of adoption. The coefficient of POM for below average adoption implies that if all the farmers decide to adopt a below average number of EBFMPs on their farms, then they would have achieved just 76\% of their livelihood outcomes and this was found to be statistically significant at $1 \%$ (Table 7). On the other hand, the coefficient of POM for above average adoption indicates that if all farmers decide to adopt above average number of EBFMPs on their farms, then they would have achieved about $79 \%$ of their livelihood outcomes and this is statistically significant at $1 \%$ (Table 7). This means that current below average adopters of EBFMPs are losing out on the full benefits of using these farming practices.

\section{Conclusions}

The study sought to determine the implications of adoption of ecosystem-based farm management practices (EBFMPs) on livelihoods of irrigation farmers in Africa using Ghana as a case study. The results show that the adoption of more EBFMPs improves water supply systems in irrigation landscapes, sustains aquatic life and livestock, maintains irrigation vegetation health, widens food security options and health treatment alternatives and also improves soil fertility and reduces cost of production. The results also show that a decision to adopt above the average number of EBFMPs considered in the study significantly improves the livelihoods of irrigation farmers. As such, the first implication of the results for policy is that policy makers and implementers should revise their "yield emphasis" and educate irrigation farmers more about the importance of using EBFMPs. They should also educate irrigators on the functioning of irrigation landscape (in terms of water flow from up-stream area to down-stream) and how their activities and practices affect the irrigation water supply system. The last implication for policy is that the focus of national irrigation policies should be on the identification, design and implementation of programs and projects that are tailored toward irrigation ecosystem management for long-term livelihood sustainability and resilience.

\section{Endnotes}

${ }^{1}$ The STATA command for regression adjustment is teffects $r a$. The menu procedure is Statistics > Treatment effects > Regression adjustment. The reference paper is Stata treatment-effects reference manual: potential outcomes/counterfactual outcomes release 13.

${ }^{2}$ Note that with regression adjustment, we do not need to specify the treatment model but only required to select the treatment variable. Details of the model can be accessed in Stata treatment-effects reference manual: potential outcomes/counterfactual outcomes release 13.

Table 7 Potential outcome means of farmers $(n=300)$

\begin{tabular}{lcc}
\hline Variables & Coefficients & Robust standard error \\
\hline Below average adoption & $75.7565^{* * *}$ & .4401 \\
Above average adoption & $78.7337^{* * *}$ & .4558 \\
Iteration 0: & & \\
$\quad$ EE criterion $=8.657 \mathrm{e}-28$ & & \\
Iteration 1: & \\
$\quad$ EE criterion $=4.547 \mathrm{e}-29$ & \\
Outcome model: linear & & \\
Treatment model: none & & \\
\hline
\end{tabular}

***, Values statistically significant at 1,5 and $10 \%$ respectively Source: Field survey, 2016 


\section{Appendix}

Table $\mathbf{8}$ Livelihood indicators of farmers and scores of measurements

\begin{tabular}{|c|c|c|}
\hline Livelihood indicators & $\begin{array}{l}\text { Scores of } \\
\text { measurement }\end{array}$ & Total score \\
\hline A. Monthly food availability & $\begin{array}{l}\text { Scores for all } \\
\text { months in the year }\end{array}$ & \multirow[t]{7}{*}{$\begin{array}{l}\mathrm{HTS}=36, \mathrm{LTS}=12 \\
\mathrm{IFIPS}_{i}^{F A}=\frac{\mathrm{IFFS}_{i}^{F A}}{36} \times 100\end{array}$} \\
\hline January & \multirow{6}{*}{$\begin{array}{l}\text { Sufficient }=3 \\
\text { Insufficient }=2 \\
\text { Extreme shortage = } \\
1\end{array}$} & \\
\hline February & & \\
\hline * & & \\
\hline * & & \\
\hline * & & \\
\hline December & & \\
\hline B. Housing conditions & $\begin{array}{l}\text { Scores for housing } \\
\text { condition } \\
\text { parameters }\end{array}$ & \multirow[t]{6}{*}{$\begin{array}{l}\mathrm{HTS}=16, \mathrm{LTS}=5 \\
\mathrm{IFIPS}_{i}^{H C}=\frac{\mathrm{IFFS}_{i}^{H C}}{16} \times 100\end{array}$} \\
\hline Ownership of house & $\begin{array}{l}\text { Personal house }=3 \\
\text { Family house }=2 \\
\text { Rented house }=1\end{array}$ & \\
\hline $\begin{array}{l}\text { Number of rooms roofed with roofing sheets (e.g. aluminium } \\
\text { or zinc sheets) }\end{array}$ & $\begin{array}{l}\text { All rooms }=3 \\
\text { Half of the rooms }= \\
2 \\
\text { Below half }=1\end{array}$ & \\
\hline Number of rooms built with cement blocks & $\begin{array}{l}\text { All rooms }=3 \\
\text { Half of the rooms }= \\
2 \\
\text { Below half }=1\end{array}$ & \\
\hline Number of rooms floored & $\begin{array}{l}\text { All rooms }=3 \\
\text { Half of the rooms }= \\
2 \\
\text { Below half }=1\end{array}$ & \\
\hline General impression & $\begin{array}{l}\text { Excellent }=4 \\
\text { Very good }=3 \\
\text { Good }=2 \\
\text { Bad }=1\end{array}$ & \\
\hline C. Health situation & $\begin{array}{l}\text { Scores for health } \\
\text { situation parameters }\end{array}$ & \multirow[t]{5}{*}{$\begin{array}{l}\mathrm{HTS}=11, \mathrm{LTS}=4 \\
\mathrm{IFIPS}_{i}^{H S}=\frac{\mathrm{IFFS}_{i}^{H S}}{11} \times 100\end{array}$} \\
\hline Availability of close-by health facility & $\begin{array}{l}\text { District hospital/ } \\
\text { community health } \\
\text { centre/CHPS } \\
\text { compound }=2 \\
\text { No health facility } \\
\text { closely available }=1\end{array}$ & \\
\hline Access to district hospital/community health centre & $\begin{array}{l}\text { All household } \\
\text { members }=3 \\
\text { Some members = } 2 \\
\text { No access }=1\end{array}$ & \\
\hline Access to herbal treatment & $\begin{array}{l}\text { Always }=3 \\
\text { Difficult }=2 \\
\text { Not at all =1 }\end{array}$ & \\
\hline Pharmacy & $\begin{array}{l}\text { Always }=3 \\
\text { Difficult }=2 \\
\text { Not at all =1 }\end{array}$ & \\
\hline D. Water facilities & $\begin{array}{l}\text { Scores for water } \\
\text { facilities parameters }\end{array}$ & \multirow[t]{3}{*}{$\begin{array}{l}\mathrm{HTS}=43, \mathrm{LTS}=14 \\
\mathrm{IFIPS}_{i}^{W F}=\frac{\mathrm{IFFS}_{i}^{W F}}{43} \times 100\end{array}$} \\
\hline Source of water & $\begin{array}{l}\text { Borehole/pipe }=4 \\
\text { Mechanised well = } 3 \\
\text { Uncovered well =2 } \\
\text { River/pond = } 1\end{array}$ & \\
\hline Perceived quality of drinking water & Good $=3$ & \\
\hline
\end{tabular}


Table 8 Livelihood indicators of farmers and scores of measurements (Continued)

\begin{tabular}{|c|c|c|}
\hline Livelihood indicators & $\begin{array}{l}\text { Scores of } \\
\text { measurement }\end{array}$ & Total score \\
\hline & $\begin{array}{l}\text { Clean but smells }=2 \\
\text { Unclean }=1\end{array}$ & \\
\hline Monthly availability of water & $\begin{array}{l}\text { Adequate }=3 \\
\text { Inadequate }=2 \\
\text { Scarcity }=1\end{array}$ & \\
\hline \multicolumn{3}{|l|}{ January } \\
\hline \multicolumn{3}{|l|}{ February } \\
\hline \multicolumn{3}{|l|}{ * } \\
\hline \multicolumn{3}{|l|}{ * } \\
\hline \multicolumn{3}{|l|}{ * } \\
\hline \multicolumn{3}{|l|}{ December } \\
\hline E. Decision-making in cash expenditure & $\begin{array}{l}\text { Scores on decision } \\
\text { parameters }\end{array}$ & $\begin{array}{l}\mathrm{HTS}=20, \mathrm{LTS}=5 \\
\mathrm{IFIPS}_{i}^{F C E}=\frac{\mathrm{IFSS}_{i}^{F C E}}{20} \times 100\end{array}$ \\
\hline Daily expenditure & \multirow{4}{*}{$\begin{array}{l}\text { Farmer }=4 \\
\text { Farmer and spouse } \\
=3 \\
\text { Spouse }=2 \\
\text { Extended family }=1\end{array}$} & \\
\hline Investment on land & & \\
\hline Children's education & & \\
\hline Households assets & & \\
\hline \multicolumn{3}{|l|}{ Health } \\
\hline F. Sanitation & $\begin{array}{l}\text { Scores on sanitation } \\
\text { parameters }\end{array}$ & $\begin{array}{l}\mathrm{HTS}=6, \mathrm{LTS}=2 \\
\mathrm{IFIPS}_{i}^{S}=\frac{\mathrm{IFFS} S}{6} \times 100\end{array}$ \\
\hline Possession of toilet & $\begin{array}{l}\text { Owned toilet }=3 \\
\text { Community toilet }= \\
2 \\
\text { None }=1\end{array}$ & \\
\hline Condition of toilet & $\begin{array}{l}\text { Hygienic }=3 \\
\text { Better }=2 \\
\text { Unhygienic }=1\end{array}$ & \\
\hline G. Participation of in social activities & $\begin{array}{l}\text { Freedom to } \\
\text { participate }=2 \\
\text { Limited freedom to } \\
\text { participate }=1\end{array}$ & $\begin{array}{l}\mathrm{HTS}=2, \mathrm{LTS}=1 \\
\mathrm{IFIPS}_{i}^{P}=\frac{\mid \mathrm{FFS} S_{i}^{P}}{2} \times 100\end{array}$ \\
\hline H. Health of ecosystem services & $\begin{array}{l}\text { Scores on health of } \\
\text { ecosystems services } \\
\text { parameters }\end{array}$ & $\begin{array}{l}\mathrm{HTS}=30, \mathrm{LTS}=10 \\
\mathrm{IFIPS}_{i}^{E C O}=\frac{\mathrm{IFFS} S_{i}^{E O}}{30} \times 100\end{array}$ \\
\hline Fish availability & \multirow{10}{*}{$\begin{array}{l}\text { Sustained }=3 \\
\text { Deteriorating }=2 \\
\text { Worsened }=1\end{array}$} & \\
\hline Vegetation for animals & & \\
\hline \multicolumn{2}{|l|}{ Availability of medical plants } & \\
\hline \multicolumn{2}{|l|}{ Fuel wood availability } & \\
\hline \multicolumn{2}{|l|}{ Fruits availability } & \\
\hline \multicolumn{2}{|l|}{ Water availability recreational purposes } & \\
\hline \multicolumn{2}{|l|}{ Flood control } & \\
\hline \multicolumn{2}{|l|}{ Erosion control } & \\
\hline \multicolumn{2}{|l|}{ Siltation control } & \\
\hline \multicolumn{2}{|l|}{ Pests and diseases control } & \\
\hline I. Income & $\begin{array}{l}\text { Scores on farm } \\
\text { income }\end{array}$ & \\
\hline \multirow[t]{3}{*}{ Category of last season's crops value (GH ) } & $\begin{array}{l}\text { Category } \\
(\mathrm{GH})\end{array}$ & \multirow[t]{3}{*}{$\begin{array}{l}\mathrm{HTS}=11, \mathrm{LTS}=1 \\
\mathrm{IFIPS}_{i}^{\text {Inc }}=\frac{\mathrm{IFFS} S_{i}^{\text {Iic }}}{11} \times 100\end{array}$} \\
\hline & $<1000$ & \\
\hline & 1001 to 20002 & \\
\hline
\end{tabular}


Table 8 Livelihood indicators of farmers and scores of measurements (Continued)

\begin{tabular}{lll}
\hline Livelihood indicators & $\begin{array}{l}\text { Scores of } \\
\text { measurement }\end{array}$ & Total score \\
\hline & 2001 to 30003 \\
3001 to 40004 \\
4001 to 50005 \\
5001 to 60006 \\
6001 to 70007 \\
7001 to 80008 \\
8001 to 90009 \\
9001 to \\
10,000 \\
$10,000+$
\end{tabular}

HTS highest total score, LTS lowest total score

Source: Adopted and modified from Sheheli (2012)

\begin{abstract}
Abbreviations
ALSS: Average livelihood status score; ATE: Average treatment effect; ATET: Average treatment effect on the treated; CAADP: Comprehensive Africa Agriculture Development Programme; CGIAR: Consultative Group on International Agriculture Research; CIS: Community-managed irrigation schemes; EBFMPs: Ecosystem-based farm management practices; ECOWAP: ECOWAS Agricultural Policy; GIS: Government-managed irrigation schemes; GSS: Ghana Statistical Service; IFFS: Individual farmers' field score; IFIPS: Individual farmer's indicator percentage score; IFPMS: Individual farmer's possible maximum score; IUCN: International Union for Conservation of Nature; IWMI: International Water Management Institute; MoFA: Ministry of Food and Agriculture; POM: Potential outcome mean; UDS: University for Development Studies; UNDP: United Nature Development Programme; WIAD: Women in Agriculture Development; WLE: Water, land and ecosystems
\end{abstract}

\title{
Acknowledgements
}

This paper is extracted from a larger study sponsored by a CGIAR Water, Land and Ecosystems Project titled "Giving 'latecomers' a head start: Reorienting irrigation investment in the White Volta basin to improve ecosystem services and livelihoods of women and youth" led by Ghana Irrigation Development Authority (GIDA) with International Water Management Institute (IVMI), University for Development Studies (UDS) and Women in Agriculture Development (WIAD) as collaborators.

\section{Funding}

This study was partly funded by a CGIAR Water, Land and Ecosystems Project titled "Giving 'latecomers' a head start: Reorienting irrigation investment in the White Volta basin to improve ecosystem services and livelihoods of women and youth" led by Ghana Irrigation Development Authority (GIDA) with International Water Management Institute (IWMI), University for Development Studies (UDS) and Women in Agriculture Development (WIAD) as collaborators.

\section{Availability of data and materials}

The dataset supporting the conclusions of this article would be provided on reasonable request.

\section{Authors' contributions}

CA designed the data collection instruments, gathered the data, analysed the data and wrote the first draft of the manuscript. MAA, FNM and SD provided guide, corrections, inputs and supervision to the entire research study. All authors read and approved the final manuscript.

\section{Authors' information}

CA, Department of Agricultural and Resource Economics, University for Development Studies, Tamale, Ghana. MAA, Institute for Interdisciplinary Research and Consultancy Services (IIRaCS), University for Development Studies, Tamale, Ghana. SD, Department of Climate Change and Food Security, University for Development Studies, Tamale, Ghana. FNM, Department of Agricultural and Resource Economics, University for Development Studies, Tamale, Ghana.

\section{Competing interests}

The authors declare that they have no competing interests.

\section{Publisher's Note}

Springer Nature remains neutral with regard to jurisdictional claims in published maps and institutional affiliations. 


\section{Author details}

${ }^{1}$ Department of Agricultural and Resource Economics, University for Development Studies, Tamale, Ghana. ${ }^{2}$ Institute for Interdisciplinary Research and Consultancy Services (IIRaCS), University for Development Studies, Tamale, Ghana.

${ }^{3}$ Department of Climate Change and Food Security, University for Development Studies, Tamale, Ghana.

Received: 14 July 2017 Accepted: 9 July 2018

Published online: 08 August 2018

\section{References}

Abdul-Hanan A, Ayamga M, Donkoh SA (2014) Smallholder adoption of soil and water conservation techniques in Ghana. Afr J Agric Res 9(5):539-546

Acheampong PP, Owusu V (2015) Impact of improved cassava varieties' adoption on farmers' incomes in Rural Ghana. Paper presented at the International Association of Agricultural Economists 2015 Conference, August 9-14, 2015, Milan, Italy

Agula C, Akudugu MA, Dittoh S, Mabe FN (2018) Promoting sustainable agriculture in Africa through ecosystem-based farm management practices: evidence from Ghana. Agric Food Secur 7(1):5

Akudugu MA, Nyamadi BV, Dittoh S (2016) Transforming smallholder agriculture in Africa through irrigation: an assessment of irrigation impact pathways in Ghana. Paper presented at the 2016 AAAE Fifth International Conference, September 23-26, 2016, Addis Ababa, Ethiopia

Assan JK, Beyene FR (2013) Livelihood impacts of environmental conservation programmes in the Amhara region of Ethiopia. J Sustain Dev 6(10):87

Boafo YA, Saito O, Takeuchi K, Gyasi E (2014) Provisioning ecosystem services in rural savanna landscapes of northern Ghana: an assessment of supply, utilization, and drivers of change. J Disaster Res 9(4):501-515

Boon E, Ahenkan A (2012) Assessing climate change impacts on ecosystem services and livelihoods in Ghana: case study of communities around Sui Forest reserve. J Ecosyst Ecogr S3:001. https://doi.org/10.4172/2157-7625.S3-001

Commission E (2009) Regional partnership compact for the implementation of ECOWAP/CAADP. http://www.oecd.org/ swac/publications/44426979.pdf. Accessed 14 Jul 2018.

Davari M, Ram M, Tewari J, Kaushish S (2010) Impact of agricultural practice on ecosystem services. Int J Agron Plant Prod 1(1):11-23

Dinye R (2013) Irrigated agriculture and poverty reduction in Kassena Nankana district in the Upper East Region, Ghana. J Sci Technol (Ghana) 33(2):59-72

Dinye RD, Ayitio J (2013) Irrigated agricultural production and poverty reduction in Northen Ghana: a case study of the Tono irrigation scheme in the Kassena Nankana District. Int J Water Resour Environ Eng 5(2):119-133

Diro BA, Regasa D (2014) Impact of micro credit on the livelihood of borrowers: evidence from Mekelle City, Ethiopia. Int Res J 3(1):25-32

Gross LH, Erickson JD, Méndez VE (2014) Supporting rural livelihoods and ecosystem services conservation in the Pico Duarte Coffee Region of the Dominican Republic. Agroecol Sustai Food Syst 38(9):1078-1107

GSS (2012) 2010 Population and housing census. Summary report of final results, Accra. http://www.statsghana.gov.gh/ docfiles/2010phc/Census2010_Summary_report_of_final_results.pdf. Accessed 14 Jul 2018.

Hancock J (2010) The case for an ecosystem service approach to decision-making: an overview. Biosci Horiz 3(2):188-196

Hapsari A (2010) Assessing and mapping ecosystem services in Offinso District, Ghana. University of Twente Faculty of Geo-Information and Earth Observation ITC, Enschede

IUCN (2004) Ecological restoration, a means of conserving biodiversity and sustaining livelihoods. International Union for conservation of Nature. https://cdn.ymaws.com/www.ser.org/resource/resmgr/custompages/publications/ser publications/MEANS OF CONSERVING BIODIVER.pdf. Accessed 14 Jul 2018

IUCN (2010) Agricultural ecosystems-facts and trends. International Union for Conservation of Nature. http://cmsdata. iucn.org/downloads/agriculturalecosystems 2.pdf. Accessed 14 Jul 2018.

Kebebe E, Shibru F (2017) Impact of alternative livelihood interventions on household welfare: evidence from rural Ethiopia. Forest Policy Econ 75:67-72

Meikle S, Ramasut T, Walker J (2001) Sustainable urban livelihoods: concepts and implications for policy. Development Planning Unit, UCL, London Working Papers 112

Millennium Ecosystem Assessment (2005) Ecosystems and human well-being, vol 5. Island Press, Washington, DC

Millennium Ecosystem Assessment (2007) A Toolkit for Understanding and Action. Protecting Nature's Services. Protecting Ourselves. Island Press. https://www.unpei.org/sites/default/files/PDF/ecosystems-economicanalysis/MEAA-Toolkit.pdf. Accessed 14 Jul 2018.

Munang R, Liu J, Chuku CA, Codjoe S, Dovie D, Mkwambisi DD, Rivington M (2011) UNEP-environment for development : putting ecosystem management in the vision of Africa's development : towards a sustainable green economy

Mwingyine DT (2008) Towards sustainable rural land use practices in the Northern Savannah Zone of Ghana: case study of the Sissala West District. KNUSTSpace, Kumasi, Ghana.

Nata JT, Mjelde JW, Boadu FO (2014) Household adoption of soil-improving practices and food insecurity in Ghana. Agric Food Secur 3(1):17

Nzama A (2009) The nexus between sustainable livelihoods and ecological management of the World Heritage Sites: lessons from iSimangaliso World Heritage Park, South Africa. Inkanyiso J Humanit Soc Sci 1(1):34-42

Ogunniyi A, Kehinde O (2015) Impact of agricultural innovation on improved livelihood and productivity outcomes among smallholder farmers in rural Nigeria. Maastricht School of Management, Maastricht, Limburg, Netherlands, pp 1-23

Raghu PT, Manaloor V (2014) Factors influencing adoption of farm management practices in agro-biodiversity hotspots of India: an analysis using negative binomial count data model. J Nat Resour Dev 04:46-53

Rezvanfar A, Samiee A, Faham E (2009) Analysis of factors affecting adoption of sustainable soil conservation practices among wheat growers. World Appl Sci J 6(5):644-651

Shackleton C, Shackleton S, Gambiza J, Nel E, Rowntree K, Urquhart P (2008) Links between ecosystem services and poverty alleviation. situation analysis for arid and semi-arid lands in southern Africa. Consortium on ecosystem and 
poverty in Sub-Saharan Africa (CEPSA), Cape Town, South Africa. https://www.unpei.org/sites/default/files/PDF/ preliminaryassessments/Links-Ecosystem-Services-and-Poverty-Alleviation.pdf. Accessed 30 Jan 2016.

Sheheli S (2012) Improving livelihood of rural women through income generating activities in Bangladesh. Humboldt Universität zu Berlin, Berlin

Sterve H (2011) Factors restricting adoption of sustainable agricultural practices in a smallholder agro-ecosystem: a case study of Potshini community, upper Thukela region, South Africa

Sudmeier-Rieux K, Masundire HM, Rizvi AH (2006) Ecosystems, livelihoods and disasters: an integrated approach to disaster risk management. IUCN, Gland, Switzerland.

Thiaw I, Kumar P, Yashiro M, Molinero C (2011) UNEP-food and ecological security: identifying synergy and trade-offs. UNEP, Nairobi, Kenya, pp 1-12

UNDP (2013) Livelihoods and economic recovery in crisis situations. http://www.undp.org/content/dam/undp/library/ crisis\%20prevention/20130215_UNDP\%20LER_guide.pdf. Accessed 14 Jul 2018.

Verbeek M (2008) A guide to modern econometrics. John Wiley and Sons, Hoboken, New Jersey, United States.

Wiafe ED, Arku FS (2014) The role of women in community based resource management on the Afadjato mountain ecosystem. Ghana Appl Res J 1(1):1-11

Zimmermann R, Bruntrüp M, Kolavalli S (2009) Agricultural policies in Sub-Saharan Africa. Understanding CAADP and APRMPolicy Processes. The German Development Institute, Bonn, Germany.

Submit your manuscript to a SpringerOpen ${ }^{0}$ journal and benefit from:

- Convenient online submission

- Rigorous peer review

- Open access: articles freely available online

High visibility within the field

- Retaining the copyright to your article

Submit your next manuscript at $\boldsymbol{\nabla}$ springeropen.com 